\title{
The Role of Psychiatrists and Muslim Faith Healers in Mental Health Issues
}

\author{
Zul Azlin Razali ${ }^{1}$ and M. Faiz Tahir ${ }^{2}$ \\ ${ }^{1}$ Faculty of Medicine and Health Science, Islamic Science University of Malaysia, ${ }^{2}$ Kuliyyah of Medicine, \\ International Islamic University of Malaysia
}

\begin{abstract}
Following the announcement of Traditional and Complementary Medicine Act 2013, Muslim faith healers are slowly gaining grounds to make their practice mainstream. One of the major characteristics of Muslim faith healers is the strong inclination to attribute mental illnesses to Jinn possession (demonic possession). Unlike other traditional healers, Muslim faith healers' primary mode of treatment is Ruqyah, an incantation or generally considered as 'Du'a or prayers. This article is a sharing by a psychiatrist who has been actively engaging with faith healers in order to understand the world of faith healing including the attitude and knowledge of both the healers and clients while attempting to educate them on modern psychiatry based on bio-psycho-socio-spiritual paradigm. The methodology: 1) Involvement in symposium, seminar and focused group discussion, either as participant or as speaker. 2) Collaborating with local spiritual leader to conduct workshop on mental illness in mosques. 3) Writing articles in scientific and popular publications with and without faith healers as the collaborators. 4) Appearing in radio advocating and discussing about the dilemma of mental illness issue from the religious perspectives, and 5) Participate in workshop conducted by Muslim faith healers. As a result, several issues come to the author's attention. The divisions of Muslim faith healers are rather complicated, for example Malay traditional healers or bomoh should not be categorized in the same group as Muslim faith healers. The oft-quoted 'Islamic Medicine' is problematic in view that it is laced with elements of local cultural value and practice which are not necessarily authentically Islamic. Since Malays make up the biggest community in Malaysia, one has to differentiate between Islam and Muslim. Majority of Muslims misunderstood the term Ruqyah as a form of healing exclusively done by the Muslim faith healers. In conclusion, psychiatrists should engage more proactively with faith and spiritual healers in order to curb stigmatization and delay in seeking psychiatric care and treatment.
\end{abstract}

KEYWORDS: Jinn, Islamic medical practice, perubatan Islam, mental health

\section{INTRODUCTION}

\section{Traditional and Complementary Medicine Act}

Malaysia has gone a long way since the1980s in their effort to incorporate traditional medicine into the national health policy. When a standing committee was formed in 1998, it soon became the talk of the town. ${ }^{1}$ Following the announcement of the Traditional and Complementary Medicine Act (T\&CM) 2013, Muslim faith healers were proud to have their representatives in the form of Darussyifa, the pioneer of 'Rawatan Perubatan Islam' (Islamic medical practice). When the revised act, T\&CM Act 7752016 was enacted, Muslim faith healers slowly gained ground to make their practice mainstream as there is now clearer stipulation about "Islamic Medical Practice'.

The Malay traditional healing practice is clearly different from allopathic medicine in that the

Zul Azlin Razali

Islamic Science University of Malaysia, Faculty of Medicine and Health Science, Menara B, Persiaran MPAJ, Jalan Pandan Utama, 55100 Pandan Indah, Kuala Lumpur, Malaysia Email: zulazlin@usim.edu.my former uses traditional or locally available herbs as medicine as well as its obvious reference to a particular ethnic tradition as the source of knowledge. However, as a Muslim and a certified medical doctor, the author takes issue on the validity of the terminology used; 'Islamic Medical Practice' or 'Rawatan Pengubatan/Perubatan Islam' $(R P I)$.In the general area of medicine, the existence of such a term gives mixed understanding and unwanted connotation among the lay public that there is 'Islamic Medicine' and other type of medicine which includes modern allopathic medicine. This implies as if a dichotomy of what is Islamic and what is not in medical practice. From the experience in the psychiatric fraternity, there are marked overlap of services which creates confusion, despite the claim that RPI Islam' gives patient more options. For example, depression is caused exclusively by Jinn (demons) and not due to chemical imbalance.It also sometimes applies reductionist view of illness neglecting the complexity of etiology of any psychiatric condition. The occurrence of so-called hysteria in schools and the public reaction towards it testify to this effect.

This paper will focus on certain aspect of RPI; ruqyah and the attribution of illnesses to Jinn. The author began his quest of learning with questions 
coming from two basic themes;

The practice of Muslim doctors.

"Why should not we, Muslim medical professionals, learn and practice ruqyah?

"What is holding us back, the Muslim medical practitioners, from embracing and learning the most important aspects of the prophetic tradition in healing practice- Du'a or ruqyah syar'iyyah?" The proper understandings on medicine from authentic Islamic perspectives.

"Jinn is a matter of unseen, al-ghaib; should we not rely heavily on authentic tradition of Quran and AsSunnah and the practice of the earlier generation of As-salafussoleh (approximately the first 250 to 300 years of Islam)?"

"Did they (As-salafussoleh) always differentiate Jinn-caused from other etiologies of any physical and mental illness?"

"Does ruqyah always being mentioned in the authentic narration hand in hand with conditions attributed to Jinn?"

\section{OBJECTIVES}

Based on the research questions above, the author embarked on this project with three objectives in mind:

To engage with faith healers in order to understand their knowledge, practice and attitude towards mental illness.

To find ways on how to inculcate professional Muslim doctors, especially psychiatric doctors, to be more aware of the needs to equip themselves with proper religious teachings and understandings in order to achieve a more holistic treatment approach.

To gain more understanding about the reasons of the existence of 'Islamic Medicine' and its relationship to modern medicine if such relationship is even present

\section{METHODOLOGY}

This paper was based on narrative, autobiographical qualitative study of the main author's journey in learning about medicine and concept of healing in Islam. Most of these activities that the author was involved took place between 2014 to 2016. The activities include formal lessons of Islamic knowledge (i.e. Diploma of Islamic Studies in a local branch of an international institution of learning), as observer in ruqyah workshop, part of the focus group in a long term research grant study by Universiti Kebangsaan Malaysia on signs and symptoms of Jinn affliction (LRGS/TD/2012/USMUKM/KT/03), personal communication with members Gabungan Persatuan Pengamal Pengubatan Islam Malaysia (GAPPIMA) and interaction with members of community through religious programmes in establishments such as mosques or radio stations where the author acted as the speaker, co-panelist or invited guest. The findings and insights gained were corroborated and enhanced with relevant literature review.

Definition of terminologies:

Practice of T\&CM

Traditional and Complementary Medicine (TCM) means a form of health related practice designed to prevent, treat or manage ailments or illness or preserve the mental and physical well being of an individual that includes such practice as traditional Malay medicine, traditional Chinese medicine, traditional Indian medicine, homeopathy, complementary therapies, but excludes medicaldental practices used by a medical-dental practitioner respectively. $^{2}$

\section{Pengubatan Islam}

Based on the website of Ministry of Health Malaysia, Pengubatan Islam was directly translated to English as Islamic Medical Practice. It is part of TCM. It is the effort of searching of treatment of physical and spiritual problems through Muslim faith healer. ${ }^{2}$

\section{PengamalPengubatan Islam}

Pengamal pengubatan Islam or Muslim faith healer is knowledgeable and skilled in treatment methods using Quranic verses, Hadith, the practices of the pious and righteous scholars, and of the venerated religious teacher; and also skilled with the use of methods or materials that are permitted by the Islamic law. Usually they are commonly known as or called ustadz, an Arabic term for teacher.

The authors took the liberty here to translate Pengamal Pengubatan Islam as Muslim Faith Healer instead of its direct translation; Islamic Medical Practice Practitioner. Two reasons drove this decision; 1) no clear differentiation in English on Perubatan and Pengubatan, as demonstrated in the Official Portal of Traditional and Complementary Medicine, Ministry of Health Malaysia. ${ }^{3}$ 2) Islam is all-encompassing. Islam does not need labeling in every aspect of life, thus Islamic medicine or Islamic medical practice should have wider interpretation. ${ }^{4}$

\section{Ruqya}

An incantation that is generally considered as ' $D u$ 'a or prayers based on hadith and al-Quran, Syari'ah compliant for the main purpose of achieving the well-being. ${ }^{3}$ t 5

\section{Findings and the discussion \\ Malay traditional healers (bomoh) and Muslim faith healers.}

Most people, those in medical fraternity included, tend to equate Muslim faith healers to bomohs or shamans. Bomoh, pawang or dukun are considered as an individual who treats people using traditional or folk medicine and traditional healing methods ${ }^{6}$ whereas Muslim faith healer has been clearly defined earlier. The former has been frequently 
associated with practices which are not in line with Islamic creed ('aqeedah) and its laws (syari'ah); i.e. khurafat, syirk. However, there is suspicion that due to the popularity of Muslim faith healers, even some bomohs rebrand themselves to be ustadz, which obviously contribute to the confusing interchangeable use of the labels.

\section{Ruqyah}

Based on the teachings of the Prophet PBUH, ruqyah is not exclusively performed by certain group of Muslims. As a form of Du'a and incantation, asking from the only all over powering God, Allah, for the healing of any ailments, the Prophet PBUH taught his companions various forms of ruqyah, originating from the hadith and the Quran. There is no indication whether some other specialties and training were needed in order to practise it. There is also no clear and strong evidence from the teaching of the Prophets PBUH that indicate ruqyah is exclusively for conditions thought to be caused by Jinn-disturbance.

However, based on his experience, the author found that most Malay Muslim including doctors, have the impression that ruqyah is something to be performed for conditions that are spiritual in origin such as affliction of Jinn. Most patients and some members of the public that the author met were not aware that self-ruqyah is important and was encouraged by our beloved Prophet PBUH. Muslim doctors also gave ambivalent response whether they should teach or at least talk about ruqyah with their patients as part of treatment.

Islamic medical practice, Islamic medicine and modern medicine

Starting off with the popular term, Perubatan Islam (Islamic Medicine), it was changed to Pengubatan Islam (Islamic medical practice) due to epistemological controversies. Not only Muslim doctors in the fraternity of allopathic medicine, the proper understanding of Islam itself lend it arguments against the usage of Islamic medicine. ${ }^{4}$ Therefore, at present it is officially known as Islamic medical practice Islamic medical practice and Islamic medicine were argued to be two different entities epistemologically and ontologically. The crucial criteria distinguishing the two were that the former lack of systematic research and its knowledge was static. ${ }^{7}$ Another term was then proposed; Perubatan Islam Komplementari (Islamic complementary medicine), which was defined as a discipline of medicine complementing the contemporary medicine with specialization in using Quranic verses and incantations, with the utilization of substance and apparatus permitted in Islam and is meant to deal with ailments afflicted by the disturbance originating from demons, or Jinn. ${ }^{7}$

Authors are concerned about the usage of the word 'Islam' in any label be it Islamic medical practice (Pengubatan Islam), Islamic medicine (Perubatan Islam), or Islamic complementary medicine
(Perubatan Islam Komplementari). Important questions are still not adequately answered; what would be the impression given to non-Muslims, or more precisely not-yet Muslims? Does this represent the all-embracing character of Islam? More importantly, how the earlier generation of Muslims (as-salafussoleh) developed, interacted with and practiced this branch of medicine? Would at-Tibbun Nabawiy be a more accurate term to adopt?

In his book Medicine in Islam, Yusuf Al-Hajj gave the definition of Islamic medicine as a medicine which is based on six basic characteristics; adhering to Islamic teachings and etiquette, adhering to logic in practicing medicine, holistic approach- paying equal attention to the body, mind and soul, universal approach-taking into account all resources, scientific approach- based on logical conclusions drawn from sound observations, accurate statistics and trustworthy experience, excellence. ${ }^{8}$ From this definition, Islamic medicine resembles much closer to current allopathic medicine, with some refinement and spiritual tuning of the latter.

\section{Attribution of symptoms of mental illness to Jinn.}

There is a huge gap of difference between some pengamal or Muslim faith healers, in which there are those who tend to believe almost any emotional turmoil is due to Jinn-disturbance and there were those who inclined to rule out psychological issues as the root cause. ${ }^{9}$ Interestingly this phenomenon is also present among Christian exorcists. ${ }^{10}$

Again, despite its popularity for decades, important questions are not dealt with in its utmost Islamic academic discourse; have we achieved the maqasid (ultimate objectives) of preserving health, aqeedah and mental capacity if we continue to include Jinncause in the equation? Or, on the other hand, would the so-called Islamic medical practice provide better way to achieve the Maqasid Syari'ah? What have authentic narration of Hadith and Seerah informed us? Divine evidence should be placed the utmost importance as a source of unseen aspect of religion such as the jinn and demons. ${ }^{11}$

\section{Muslim faith healer as our brothers}

Engagement is paramount. Despite the lack of scientific evidence and at times the lack of authentic resources on which they base some of their practice, together we are brothers in arms to fight against khurafat and syirik practiced by some irresponsible healers. ${ }^{12}$

\section{CONCLUSION}

Rather than answering the research queries, more questions were raised during this journey. By including 'Islamic medical practice', are we unintentionally secularizing this form of medicine further? Islamic complementary medicine or Muslim professional doctors who practice integrative medicine; which is more important? To where 
should our precious national resources be channeled? ${ }^{13}$

Muslim faith healers play a significant role in mental health issues. They are the most popular initial choice of treatment for emotional and psychological conditions. Muslim psychiatrists should engage more proactively with faith and spiritual healers in order to curb stigmatization and delay in seeking psychiatric care and treatment. The best Muslim psychologists and psychiatrists should be more alert and willing to learn about the aspect of faith healings. The followings are the recommendation by the authors.

\section{RECOMMENDATIONS}

\section{Engagement}

Collaborating with faith healers to organize academic workshop involving all relevant branches of academicians, including those who are not practitioners. We need more input from the bridging scholars, who are well-versed in classical Islamic scholastic tradition as well as knowledgeable in scientific discursive analysis. Collaborating with faith healers in doing research and to write or present papers in scientific conferences.

\section{Advocacy}

A Muslim psychiatrist is able to do mental health advocacy better if he or she is better equipped with proper understanding and knowledge on maqasid syari'ah in medicine and the knowledge on Jinn and ruqyah from the divine sources.

\section{Research}

A.Qualitative study (content analysis and in-depth interview of scholars) on Islamic knowledge tradition such as the life story of the prophet (Seerah an-Nabawiyah) and the classical text in the following generation of as-Salafussoleh in regards to mental health and mental illness and whether Jinn attribution is always been made.

B. Qualitative study of the scientific documents (content analysis) during the time of Islamic golden medieval era regarding mental health and mental illness and whether Jinn attribution is always been made.

C.Fundamental research in looking for guideline for mental health service based on the findings from the above two, especially in regards to Jinnaffliction.

D. The study on knowledge, attitude and practice of Muslim faith healers in dealing with mental illnesses (ongoing project under research grant) .

E.The study on knowledge, attitude and practice of Muslim physicians/doctors, generally, and psychiatrist, specifically, on ruqyah syar'iyyah, jinn and tibban nabawi. f. A serious look into medical syllabus for room of improvement in order to empower future Muslim doctors with more holistic attitude, more comprehensive knowledge divine and worldly, and more integrated practice in their clinical work.

g. Objective study utilizing technology such as radiological, biochemical etc. to investigate demonic possession and its relationship with the administration of different mode of treatment such 'Islamic medical practice' and the allopathic medicine.

Muhammad Idris ash-Shafie said "Two categories (of professionals) are indispensable to individuals: religious scholars for the religion and medical doctors for their health" ${ }^{14}$

\section{REFERENCE}

1. Teh Li Yin. Traditional and Complementary Medicine (T\&CM)- What Should You Know? Paper presented in National Regulatory Conference 2015, “Transformation Towards A New Regulatory Paradigm”, 4th-6th August 2015, One World Hotel, Malaysia. Available at http://tcm.moh.gov.my/v4/modules/mastop_p ublish/?tac=48. Accessed October 1, 2016.

2. Undang-Undang Malaysia. Akta 775, Akta Perubatan Tradisional dan Komplementari 2016. Percetakan Malaysian Nasional Berhad. 2016. Available at http: / / www.federalgazette.agc.gov.my/output aktap/aktaBM_20160310_WJW006216Akta775BM.pdf. Accessed October 1, 2016.

3. $\mathrm{MOH}$. Garis Panduan Amalan Pengubatan Islam. Bahagian Perubatan Tradisional dan Komplementari. Ministry of Health of Malaysia. Kuala Lumpur. 2011. Available at http: / / tcm.moh.gov.my/v4/pdf/guideline/GPP engubatanlslamSept2011.pdf. Accessed October 3, 2016.

4. Kasule O.H. Islamic Medical Education Resources 01. 9505- Islamic Medicine: Concept and Misunderstandings. 1995. Available at http://omarkasule-01.tripod.com/id230.html. Accessed October 3, 2016.

5. Bilal Philips. The Exorcist Tradition in Islam. AlHidayah Publishing and Distribution. Birmingham. 2007

6. DBP. Kamus Dewan Edisi Keempat. Dewan Bahasa Pustaka. Kuala Lumpur. 2015

7. Supyan Hussin and Norazian Abd Rahman. Konsep, definisi dan skop perubatan dan pengubatan. Paper presented in Simposium Perubatan Islam 2016: Ke Arah Perubatan Islam Yang Profesional Dan Kontemporari by LRGS/D/2012/USM-UKM/KT/03 research group in Universiti Kebangsaan Malaysia on 26-27 April 2016.

8. Yusuf Al Hajj Ahmad. The Islamic Guideline on Medicine. Darussalam. Riyadh. 2010.

9. Wahid Abdusalam Bali. The Cutting Edge- How to Face Evil Sorcerers. Translated by Haytham Kreidly. (Al-Sarim al-Battar Fi al-Tassadilil- 
Sahara al-'Ashrar). Dar al-Kotob al-Ilmiyah.

Beirut. 1990.

10. Martin M. Hostage to the Devil- The Possession and Exorcism of Five Contemporary Americans. HarperOne. San Fransisco. 1992.

11. Al-Tayyar A., Mubarak S. \& Hanif A. The Jinn, magic and evil eye. Darussalam. 2013.

12. Kasimin, A. Amalan sihir masyarakat Melayu: satu analisis. Percetakan Watan. 1997.

13. Zul Azlin. Perubatan Bersepadu: Integrasi Atau Komplementari. Paper presented in Simposium Perubatan Islam 2016: Ke Arah Perubatan Islam Yang Profesional Dan Kontemporari by LRGS/D/2012/USM-UKM/KT/03 research group in Universiti Kebangsaan Malaysia on 26-27 April 2016.

14. Muhammad Musharraf Hussain. Medicine and Pharmacy in the Prophetic Traditions Volume 1. International Islamic Publishing House. Riyadh. 2014. 